\title{
Collagens in ocular tissues
}

\author{
G E Marshall, A G P Konstas, W R Lee
}

\section{Collagens - general comments}

There has, within the past decade, been an explosive growth in the literature concerning collagens, their function, and their influence on cell behaviour. The purpose of this review is to outline briefly the fundamental characteristics of collagens and to relate their distribution and function to the requirements of various ocular tissues.

Collagens are a family of highly characteristic fibrous proteins, constituting a quarter of the total protein in mammals, and are produced by many cell types. At least 12 different types of collagen have been described in mammalian tissue (types I-XII) and these differ from one another in their structure, function, and tissue distribution. ${ }^{1}$ The first collagen types to be identified were those present in striated fibrils (I-III). Subsequently it was appreciated that collagens also existed in other forms such as basement membranes (IV and V) and as filaments (VI, VII, IX, and XI). At the present time only collagen types I-IX have been located within ocular tissues.

\section{STRIATED COLLAGENS}

Striated collagens are easily recognised by transmission electron microscopy since they possess a striking $65 \mathrm{~nm}$ banding pattern (Fig 1). Cells secrete collagen as tropocollagen molecules which are then assembled into striated collagen fibrils outside the cells. The cellular synthesis and extracellular assembly of tropocollagen molecules into collagen fibrils are diagrammatically summarised in Figure 2.

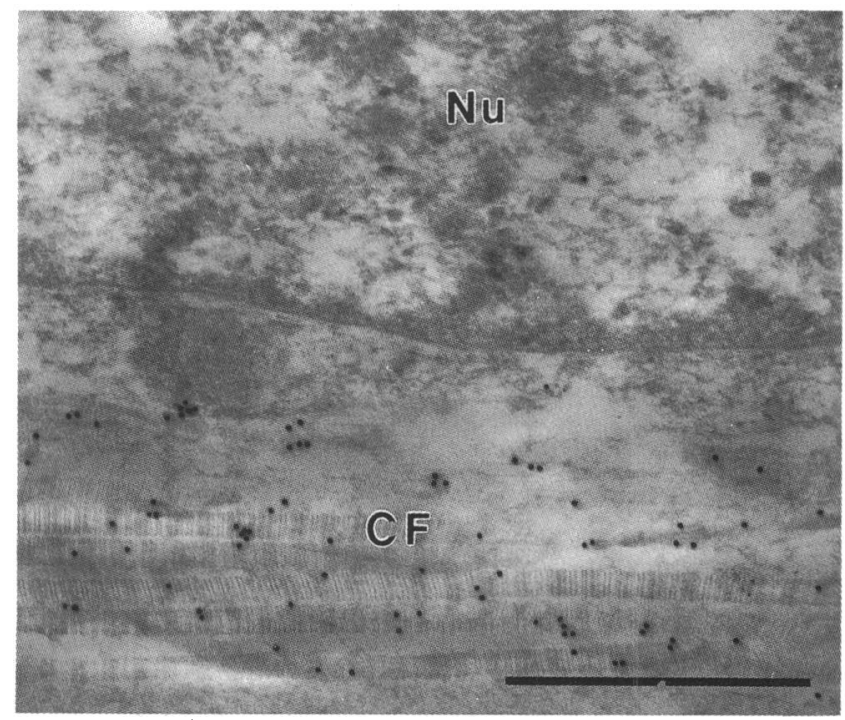

Figure 1 High magnification of human sclera illustrating the classic banding pattern of the striated collagen fibrils $(C F)$. These fibrils have been labelled with goat primary antibodies against type $V$ collagen. The primary antibodies have been made visible in the transmission electron microscope by incubation with rabbit anti-goat antibodies that have been tagged with 10 $n m$ diameter gold particles. Note absence of immunogold particles from nucleus $(\mathrm{Nu})$ of fibrocyte. These particles are seen as dark spots. (LR white, $\times 62000$, bar $=0.5 \mu \mathrm{m}$.)
While all striated collagen fibrils exhibit a similar $65 \mathrm{~nm}$ banding pattern, each fibril can contain one of a variety of collagen types (types I-III and V). Although a striated fibril can be composed of a single collagen type, co-assembly of two collagen types within the same fibril (heterotypic fibrils) has been described. ${ }^{2}$ Accurate identification of individual collagen types requires electron microscopical immunogold labelling of the fibrils with antibodies against the specific collagen type (Fig 1).

All connective tissues in which morphologists have noted the presence of collagen fibres contain type I collagen. The function of type I collagen is to give tissue tensile strength. Type II collagen is principally present in cartilage and type III collagen is associated with tissues and organs that require a motile structural scaffolding such as uterus, arteries, skin, intestines, and lung. ${ }^{3}$ Type $\mathrm{V}$ collagen occurs in many situations and one of its many functions may be the anchoring of basement membranes to their underlying stromal matrix. ${ }^{4}$

\section{BASEMENT MEMBRANE COLLAGENS}

Basement membranes are continuous, thin mats of

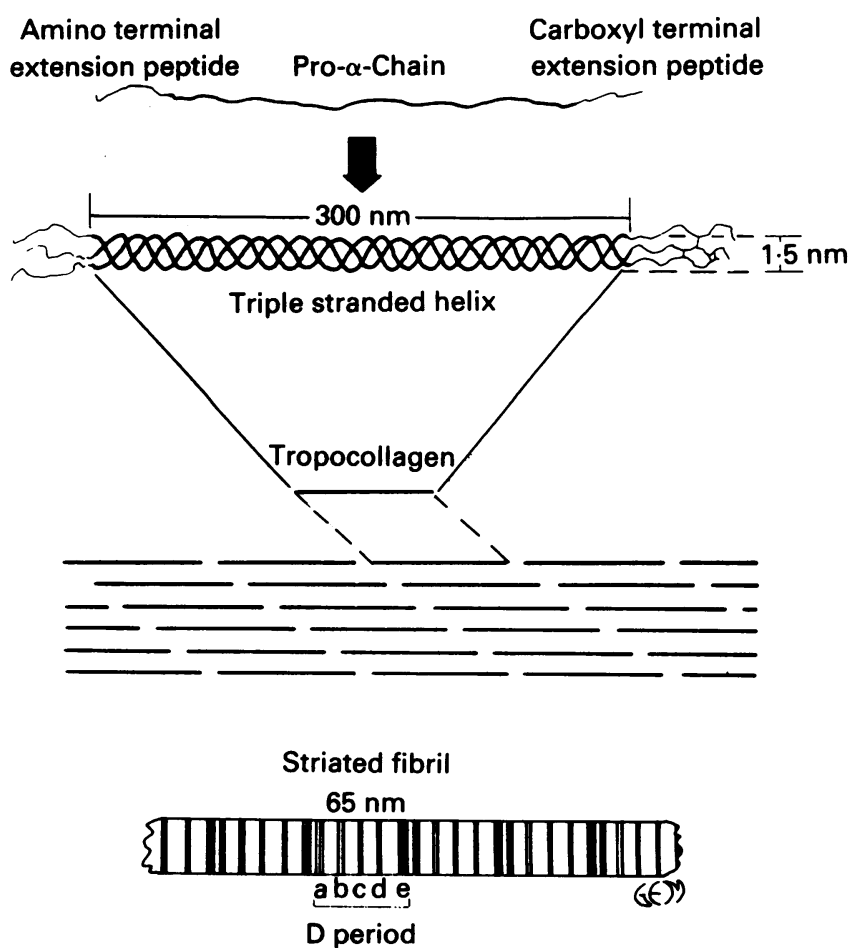

Figure 2 Diagram of collagen type I synthesis. Collagen $\alpha$ chains are initially synthesised in the form of pro- $\alpha$-chains (top) that contain extension peptides that will later be removed. Three pro- $\alpha$-chains combine to form a triple stranded helix (tropocollagen) within the cell before secretion into the extracellular matrix. Note that the carboxyl extension peptides of the triple extracellular matrix. Note that the carboxyl extension peptides of the triple
stranded helix are covalently linked together. Extracellular tropocollagen molecules are arranged in a quarter staggered array in the striated fibril. Striated fibril shows detail of five bands (a-e) that comprise the $65 \mathrm{~nm}$ repeat $D$ period. 


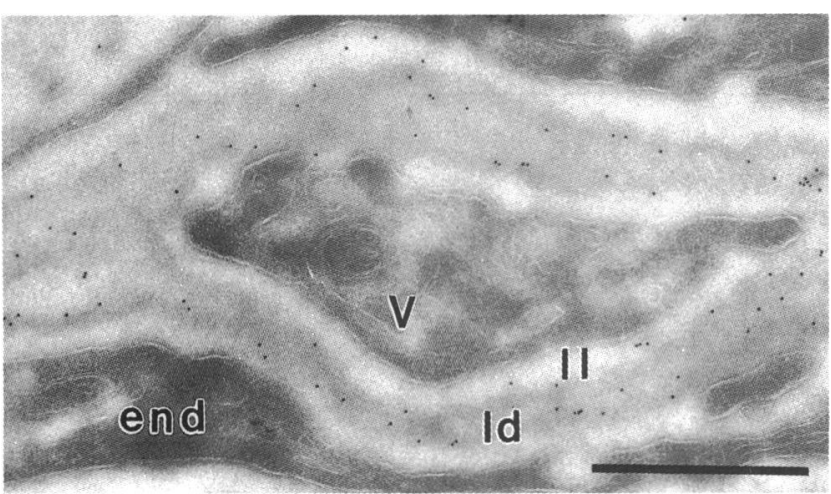

Figure 3 Basement membranes of retinal vessel. The lamina lucida $(l l)$ and lamina densa $(l d)$ are quite distinct. The basement membrane of the endothelial cell (end) is fused with that of a vascular supporting cell $(V)$ so that the lamina fibroreticularis is absent. The basement membranes in this illustration have been labelled for type IV collagen which is present only in the lamina densa. (Cryoultramicrotomy, $\times 38000$, bar $=0.5 \mu \mathrm{m}$.)

specialised extracellular matrix that underlie all epithelial cell sheets and endothelial tubes; basement membranes also surround individual muscle cells, fat cells, and all neural connective tissue cells. The basement membrane separates cells from adjacent connective tissue and in certain sites serves as a highly selective filter (for example, kidney glomerulus). ${ }^{5}$ Basement membranes have many functions such as the determination of cell polarity, the induction of cell differentiation, and the supply of 'highways' for cell migration. ${ }^{5}$ Conventional transmission electron microscopy of a typical basement membrane (Fig 3) reveals a three layered structure consisting of a lamina lucida, a lamina densa, and a lamina fibroreticularis (reviewed by Abrahamson $^{6}$ and Inuoe $^{7}$ ). This widely accepted nomenclature of the basement membrane ${ }^{8}$ has recently been challenged by Kadoya and Yamashina ${ }^{9}$ who considered the electron lucent lamina lucida to be an artefact of glutaraldehyde osmium tetroxide fixation.

The principal components of basement membranes are type IV collagen, laminin, and heparan sulphate proteoglycan. ${ }^{6}$ Type IV collagen is a non-fibrillar collagen which is only found within basement membranes. ${ }^{6}$ Type $\mathrm{V}$ collagen has also been detected, biochemically, in basement membranes of human placenta, skin, muscle, lungs, bones, and cartilage. ${ }^{10}$ In addition, type $\mathrm{V}$ collagen has been shown immunohistologically, to be co-distributed with type IV collagen in basement membranes of the kidney. ${ }^{11}$

Basement membranes form a three dimensional scaffold to which, for example, vascular cells are attached. The structural elements of the basement membrane scaffold are most probably collagen types IV and V. Their insolubility and stability make collagen types IV and V (in addition to collagens I-III) ideal scaffolding proteins. ${ }^{12}$

\section{FILAMENTOUS COLLAGENS}

Filamentous collagens can be subdivided into pericellular and matrix collagens. They sometimes form loosely aggregated fibrils with little or no periodicity but are frequently much finer than striated collagen fibrils. Types VI, VII, IX, and $\mathrm{X}$ are classified as filamentous collagens.

Although type VI collagen occurs in the vicinity of striated collagen fibrils, it is absent from the fibrils themselves, and is located to a fine filamentous network associated with the striated fibril bundles. ${ }^{13}{ }^{14}$ In skin, type VI filaments are highly concentrated around endothelial basement membranes and form a loose sheath around the blood vessels, as well as nerves and fat cells. Burgeson ${ }^{15}$ has suggested that the loose sheath of type VI collagen filaments serves to separate blood vessels, nerves, and fat cells from bundles of striated fibrils which make up tissue compartments: this also provides free movement between striated fibril bundles and cellular elements.
Anchoring fibrils are specialised fibrous structures thought to secure epithelial basement membranes to the underlying connective tissue matrix (Fig 4). ${ }^{15}$ Type VII collagen has a distribution which correlates with that of anchoring fibrils, being present at the epithelial stromal interface of cornea, amnion, oral and vaginal mucosae, and adjacent to the basement membrane of the dermal epidermal junction of skin. ${ }^{15}$

Type VIII collagen is synthesised by cell cultures of bovine corneal endothelial cells and aortic endothelial cells. ${ }^{16-19}$ It is predicted that this collagen type is a minor component of most mesenchymal tissues including the vascular tree and, as it forms part of the basement membrane, type VIII collagen may be closely associated with the cell surface. In vitro studies indicate that type VIII collagen is essential for the maintenance of the endothelial cell phenotype..$^{20}$

Type IX collagen is unique among the collagens in being covalently attached to a glycosaminoglycan, chondroitin sulphate. ${ }^{21}{ }^{22}$ The function of type IX collagen is unknown but it appears to be associated with the surfaces of banded cartilage fibrils with a portion of the triple helix projecting out at an angle from the fibril surface which may serve to terminate increases in fibril diameter. ${ }^{15}$

\section{Ocular collagens}

The distribution of collagen types within ocular tissues is indicated in Table 1.

\section{Cornea}

\section{BIOCHEMICAL DATA}

Collagen forms $71 \%$ dry weight of the cornea ${ }^{23}$ and biochemical analysis reveals that the mammalian cornea contains substantial amounts of type I collagen. Collagen types III (more than $10 \%$ dry weight), ${ }^{24} 25 \mathrm{~V}$ (about 5\%), ${ }^{24}$ and VI (not quantified $)^{26}$ have been biochemically identified in the human cornea. Type IV collagen has not been detected and there is general agreement that type II collagen is absent from the human cornea. ${ }^{24}$ 27-31 Biochemical data concerning collagen types VIII-XII are not available.

\section{COLLAGENS IN CORNEAL EMBRYOGENESIS}

The chick cornea has been the principal tissue used to study

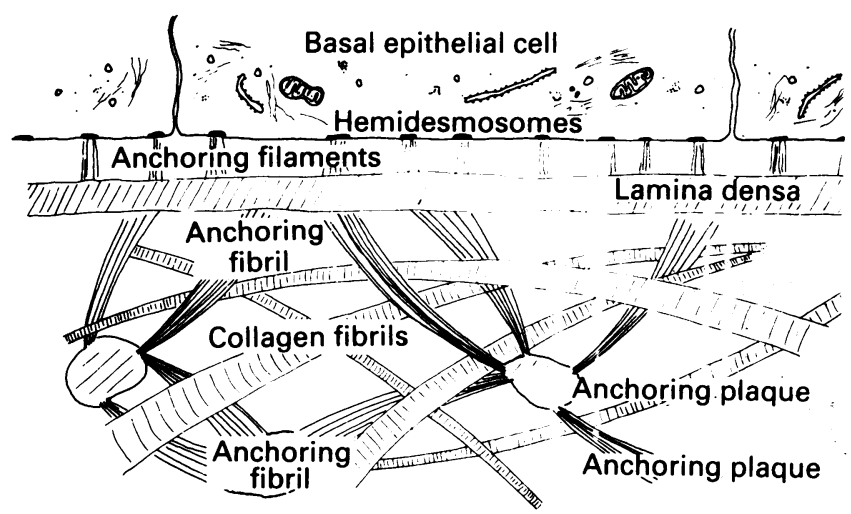

Figure 4 Diagrammatic representation of basement membrane complex. Hemidesmosomes rivet epithelium to underlying lamina densa (basement membrane) by means of anchoring filaments which cross the lamina lucida (lamina rara externa) at right angles. Anchoring fibrils project into Bowman's layer from the lamina densa, attaching the lamina densa to anchoring plaques and form a large scaffold throughout the sub-basal lamina (lamina rara interna) which entraps large numbers of collagen fibrils. ${ }^{+2+3}$ It is the entrapped collagen fibrils that prevent the anchoring fibril network from being pulled out of Bowman's layer. The anchoring fibril network prevents the lamina densa from separating from Bowman's layer " and hemidesmosomes prevent the epithelium from separating from the lamina densa. Thus is the epithelium anchored to Bowman's layer. 
Table 1 Summary of distribution of various collagen types in ocular tissues

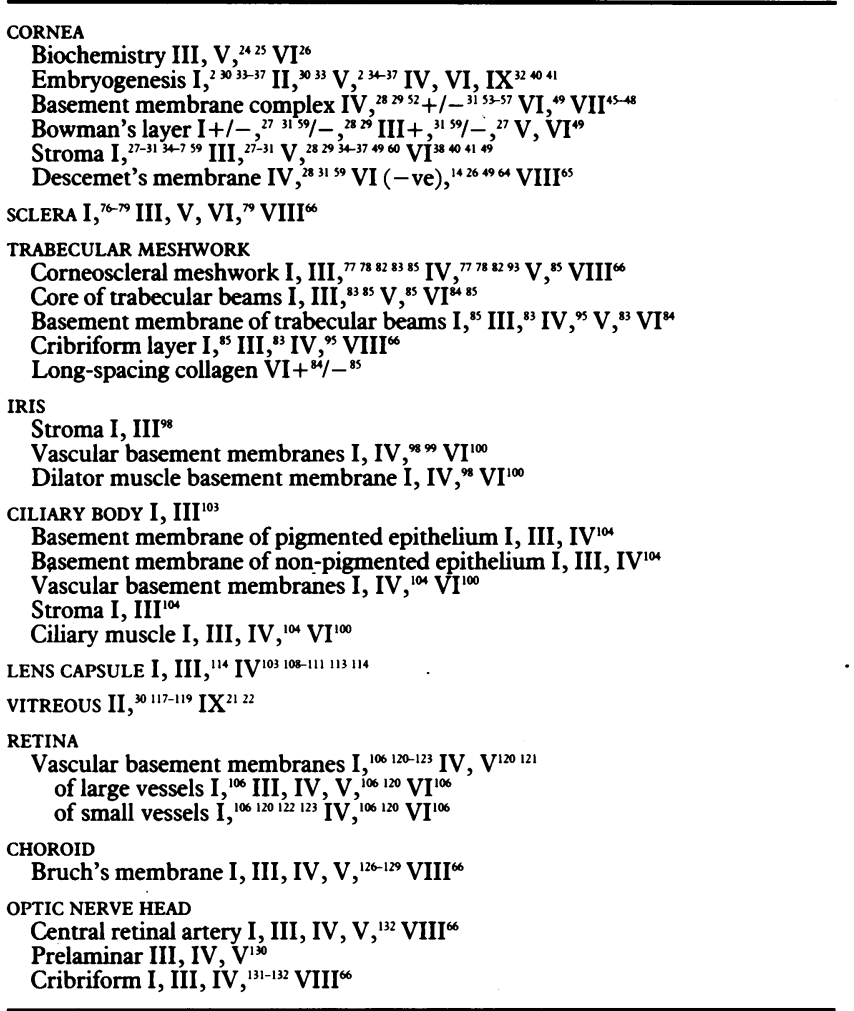

the involvement of collagens in ocular development (reviewed by Linsenmayer $e^{2} a^{32}$ ) and is of particular interest because various collagen types participate, sometimes transiently, in this complex process. The primary stroma is laid down by the corneal epithelium and consists of types I and II collagen which are co-assembled into each striated fibril. ${ }^{30}$ Invading pericorneal mesenchymal cells differentiate into stromal fibroblasts and synthesise heterotypic fibrils of types I and V collagen. ${ }^{234-37}$ Type VI collagen appears very rapidly at this stage in embryogenesis ${ }^{38}$ and is thought to direct the migration of invading fibroblasts. ${ }^{39}$ In a transient stage in embryogenesis, filaments of types IV, VI, and IX collagen ${ }^{404}$ extend from the epithelial side to the endothelial side of the developing cornea. Type IV collagen is present during this phase in a non-basement membrane form, consisting of long strings radiating from the epithelial basement membrane to deep within the corneal stroma. ${ }^{32}$ The mature stroma is mainly synthesised by the stromal fibroblasts, the heterotypic fibrils consisting of types I and V collagen. Type VI collagen is thought to stabilise the whole structure. ${ }^{32}$ Type IX collagen appears in the embryonic chick cornea at the same time as endothelial cells begin migrating along the posterior surface of the stroma. It is not known if endothelial migration is induced by, or triggers the deposition of type IX collagen. ${ }^{32}$ Type IX collagen is only present for a short period and disappears rapidly before primary stromal swelling. This suggests that type IX collagen maintains the compactness of the primary stroma, probably by forming bridges between striated fibrils and its removal may be the trigger for the invasion of pericorneal mesenchymal cells into the primary stroma. ${ }^{32}$

\section{THE EPITHELIAL BASEMENT MEMBRANE COMPLEX}

Corneal epithelial adhesion is maintained by a specialised structure, the basement membrane complex which anchors the epithelium to Bowman's layer. Although a basement membrane complex is present in the skin, that of the cornea is a more highly developed form. ${ }^{124-44}$ This highly developed adhesion complex may compensate for the lack of a rete peg system which is present in the epidermis (see Fig 4 for a diagrammatic representation of the epithelial basement membrane complex). Several workers have demonstrated that anchoring fibrils contain type VII collagen as a primary structural element. ${ }^{45-48}$ Type VI collagen is present in the anchoring plaques. ${ }^{49}$ The constituents of anchoring filaments are not yet identified.

The well established concept that anchoring plaques are trapped in the meshwork of collagen fibrils in Bowman's layer $^{42430}$ has been questioned by Wasano and Yamamoto ${ }^{51}$ who noted very little entrapment of corneal connective tissue elements by the anchoring fibril network. ${ }^{51} \mathrm{We}$ found that type VI collagen, in addition to being present in anchoring plaques forms a filamentous network around striated collagen fibrils and therefore may serve to attach the anchoring plaques to this filamentous network in Bowman's layer. ${ }^{49}$ Thus anchoring plaques may be secured within Bowman's layer by virtue of their incorporation within this filamentous network of type VI collagen.

The nature of the basement membrane of the corneal epithelium remains controversial. Although some immunofluorescent studies report the presence of type IV collagen beneath the human corneal epithelium, ${ }^{28} 2952$ other investigations failed to detect it in this region. ${ }^{3153-57}$ The most exhaustive study ${ }^{53}$ found type IV collagen to be abundantly present in the conjunctival and limbal basement membranes but immunoreactivity disappeared within a short distance of the start of Bowman's layer, despite the use of a large number of unmasking treatments to expose the antigenic epitope. Loose adhesion between Bowman's layer and the epithelial basement membrane is a feature of diabetes in which basement membrane remains attached to epithelium removed from Bowman's layer. ${ }^{58}$ This phenomenon is attributed to decreased penetration of anchoring fibrils in the diabetic cornea. ${ }^{58}$

\section{STROMAL COLLAGENS}

The distribution of collagen types I-VIII is diagrammatically summarised in Figure 5. Various immunolabelling methods have been employed to demonstrate the presence of collagen types I, ${ }^{27-3159}$ III, ${ }^{27-31} \mathrm{~V},{ }^{28293434374960}$ and $\mathrm{VI}^{49}$ in the human corneal stroma. In immunogold studies, labelling for all three collagen types is present on every fibril ${ }^{31}{ }^{49}$ which suggests coassembly (co-distribution) of these three collagen types within the same striated fibril. Co-assembly of type I and type $\mathrm{V}$ collagen has been demonstrated clearly in chick cornea using a double labelling technique ${ }^{23}$ and further evidence for their co-assembly has been derived from enzyme digestion studies of Fitch et al. ${ }^{61}$

Attempts to document the distribution of collagen types I-IV in the human cornea using immunofluorescence have not yielded consistent results. Type I collagen has been reported as both present in ${ }^{27} 59$ and absent from ${ }^{28} 29$ Bowman's layer of the human cornea. There is also some disagreement concerning the presence and distribution of type III collagen in humans. Ben-Zvi et $a l^{27}$ reported its absence in adults and presence only within the first 28 weeks of gestation. In contrast, Newsome et $a l^{59}$ found type III to be present in Bowman's layer and on the edges of stromal lamellae. Three other studies reported the presence of type III throughout the corneal stroma. ${ }^{28} 2931$ It should be noted that the occurrence of type III collagen in the corneal stroma appears to be unique to the human eye.

Type VI collagen has been localised to fine filamentous structures in the human cornea. ${ }^{49}$ These filamentous structures are quite distinct from striated collagen fibrils and are probably located between them ${ }^{38}$ Consequently it has been concluded that type VI collagen is not incorporated into the 


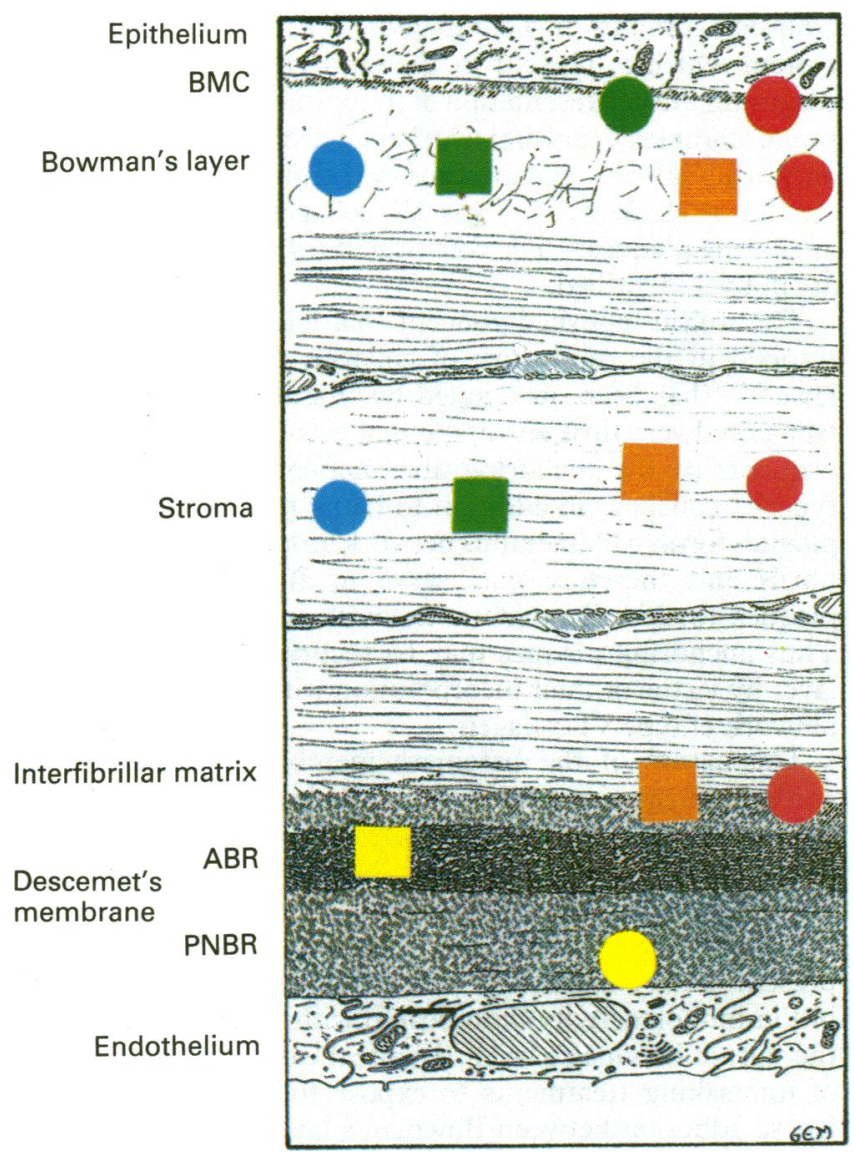

Figure 5 Summary diagram of the distribution of collagens I-VIII in aged human cornea. Collagens I (blue circle), III (green square), V (brown square), and VI (red circle) are evenly distributed throughout Bowman's layer and the cormeal stroma. Types V (brown square) and VI (red circle) are also present in the interfacial matrix. Type IV collagen (yellow circle) is present in Descemet's membrane. Both types VI (red circle) and VII collagen (green circle) are present in the basement membrane complex (BMC) immediately underneath the epithelium. Type VIII collagen (yellow square) is present in the anterior banded region $(A B R)$ of Descemet's membrane. $P N B R=$ posterior non-banded region.

striated collagen fibrils but remains in the interfibrillar matrix. ${ }^{15384962}$

\section{DESCEMET'S MEMBRANE}

Although type IV collagen has been located in Descemet's membrane both by immunofluorescence 2859 and by immunoelectron microscopy, ${ }^{31}$ agreement is not forthcoming on its precise distribution. In two studies ${ }^{28} 29$ labelling was restricted to the stromal interface, but subsequently Newsome et $a l^{59}$ observed two discrete layers, one at the stromal face and one at the endothelial face. This led to the suggestion that the unstained middle portion corresponded to the anterior banded region (Fig 5) observed in conventional electron microscopy. We found, by immunoelectron microscopy, that type IV collagen was concentrated at the endothelial face of Descemet's membrane. ${ }^{31}$ We also located types V and VI collagen between the most posterior lamella and the posterior non-banded layer (interfacial matrix; Fig 5). ${ }^{49}$ As these collagens also encroached into a narrow margin of the anterior portion of Descemet's membrane, we suggest that they are involved in the tenuous welding of Descemet's membrane to the corneal stroma.

The elegant hexagonal pattern of the matrix present in the anterior region of Descemet's membrane has been ascribed to the presence of type VI collagen. This is because the node to node distance in its hexagonal matrix is similar to the distance between the globular domains of type VI collagen filaments. ${ }^{63}$
However, immunofluorescence studies have not located type VI collagen in Descemet's membrane, ${ }^{14264}$ either with or without treatment to increase the availability of type VI collagen to antibody binding (hyaluronidase; acetic acid). ${ }^{64}$ In addition, the hexagonal matrix in our immunoelectron microscope study exhibited minimal labelling for this collagen type in the human cornea and we concluded that type VI collagen is not responsible for the hexagonal matrix morphology of the anterior banded region (Fig 5). ${ }^{49} \mathrm{~A}$ recent study has demonstrated the presence of type VIII collagen in the hexagonal matrix of bovine Descemet's membrane by immunoelectron microscopy. ${ }^{65}$ Type VIII collagen is secreted by most endothelial cells in culture, and was originally termed endothelial collagen.$^{20}$ In addition to Descemet's membrane, type VIII collagen has also been localised by light microscopic immunohistochemistry to the trabecular meshwork, the wall of Schlemm's canal, Bruch's membrane, the choroidal stroma, sclera, central retinal artery, and cribriform plates of the optic nerve head. ${ }^{66}$

\section{CELLULAR SYNTHESIS OF EXTRACELLULAR MATRIX}

The unique compartments of the cornea make it ideal for the correlation of the immunomorphologic location of collagen types to the synthetic capability of the associated cell types. Several cell culture studies have been conducted on the biosynthesis of extracellular matrix components by corneal keratocytes, epithelial, and endothelial cells. Rabbit corneal endothelial cell cultures synthesise mainly type IV collagen plus small amounts of type III and VIII collagens. ${ }^{1967}$ However, considerable caution must be exercised in assessing cell culture studies of extracellular matrix synthesis as the biosynthesis may be a tissue culture specific phenomenon. It is likely that organ cultures give more reliable indications of the biosynthetic activities in vivo. The following is a case in point. Radiolabelled proline was incorporated by cultured bovine corneal endothelial cells mainly into type III collagen ${ }^{68}$ plus small amounts of collagens I, IV, and V, but only types I and IV collagen were radiolabelled in organ cultures of bovine Descemet's endothelial complex. ${ }^{68}$ It was concluded that type III synthesis was a tissue culture induced phenomenon specific to bovine corneal endothelial cells. Perhaps the most satisfactory method of determining the synthetic capabilty of extracellular matrix associated cells is by the determination of mRNA expression of specific extracellular matrix components by individual cells (in situ hybridisation).

\section{TRANSPARENCY AND FIBRIL DIAMETER CONTROL}

The almost perfect transparency of the cornea is thought to be due to the uniform diameter and regular interfibrillar distance of the striated fibrils within the stroma ${ }^{69}$ The presence of type $\mathrm{V}$ collagen is one of many factors influencing fibril diameter. ${ }^{36}$ Type $\mathrm{V}$ collagen has a greater concentration in the cornea than in sclera, tendon, bone, and dermis ${ }^{70-72}$ and is thought to influence fibril diameter in the corneal stroma through its longer helix ${ }^{7073}$ and the presence of a unique terminal globular domain. ${ }^{70}$ Uncontrolled accretion of type I collagen onto the surface of a fibril would be prevented by incompatibility with the 'non-fitting' type $\mathrm{V}$ molecule already present on the fibril surface. In vitro fibrillogenesis studies employing mixtures of collagen types I and V, show that the average diameter of the heterotypic fibrils formed decreases as the ratio of type $\mathrm{V}$ collagen in the mixture is increased. ${ }^{74}$ The regular interfibrillar distance is probably achieved by the proteoglycans chondroitin (dermatan) and keratan sulphate forming bridges between the fibrils. ${ }^{75}$ However, fundamentally important though they be, consideration of proteoglycans is outside the scope of this review. 
ADVANTAGES OF COLLAGEN CO-ASSEMBLY

Co-assembly of two different collagen types may have the advantages of imparting regulatory information (such as influencing fibril diameter) and the need for more than one collagenase in turnover and degradation. An interesting hypothesis has been put forward by Linsenmayer $e t \mathrm{al}^{32}$ on the importance of enzymes in corneal re-modelling. The release of collagenase $\mathrm{I}$ and collagenase $\mathrm{V}$ into the chick cornea would produce a loose filamentous matrix of random orientation, largely composed of type VI collagen, noncollagenous microfibrils, and proteoglycans. The activity of only collagenase I would also result in a loose filamentous matrix. However, the corneal lamellae would still have the same original spatial organisation as the skeleton would be preserved by the type $\mathrm{V}$ collagen fibrils. The surviving skeleton might then serve as a template for directing the assembly of a new connective tissue matrix similar in structure to the original stroma.

\section{Scleral collagens}

Type I collagen has been identified, biochemically, in human sclera with no apparent variation in its percentage of tissue mass between the equatorial and posterior regions. ${ }^{76}$ Although four collagen types (I-IV) were studied by immunohistochemistry, only type I collagen was positively localised..$^{78}$ Our fine structural immunogold studies of aged human sclera indicate that collagen types I, III, and V are present and may well be co-assembled within individual collagen fibrils, since every fibril exhibited labelling for all three collagen types at some point along its length. ${ }^{79}$ Transverse sections of collagen fibrils revealed a preferential location of type $\mathrm{V}$ to the fibril surface. Both types V and VI collagen were localised to filamentous strands in the interfibrillar matrix. This filamentous material formed short bridges between adjacent fibrils. Such filamentous strands have been observed in both cornea and sclera that had been quick frozen and deep etched for scanning electron microscopy. ${ }^{80}$ Both types II and IV collagen were absent from the scleral stroma.

\section{COMPARISON OF SCLERA WITH CORNEA}

The putative role of type $\mathrm{V}$ collagen in maintaining uniform fibril diameter in the corneal stroma has already been discussed. The collagen constitutents of the cornea and the sclera are essentially the same, but scleral collagen fibrils exhibit a wide range of diameters and it therefore must be assumed that type $\mathrm{V}$ collagen present in the sclera does not play the same role as it plays in the cornea. This discrepancy requires further consideration. It may be advantageous for the scleral fibrils to have such a large variation in diameter: both large and small fibrils probably have a separate function that contributes to the biomechanical properties of the sclera. Large diameter fibrils, in having a greater density of cross linking between collagen molecules, impart greater tensile strength. ${ }^{81}$ Small diameter fibrils have a greater surface area of contact with the surrounding matrix and the increased amount of interaction between the fibrils and proteoglycans may endow greater creep resistant properties (the sliding of fibrils past each other ultimately resulting in stretching of the tissue).$^{81}$

\section{Trabecular meshwork}

LOCATION OF MESHWORK COLLAGENS

The distribution of collagens in the meshwork is diagrammatically summarised in Figure 6 . Three early light microscopic immunohistochemical investigations identified types

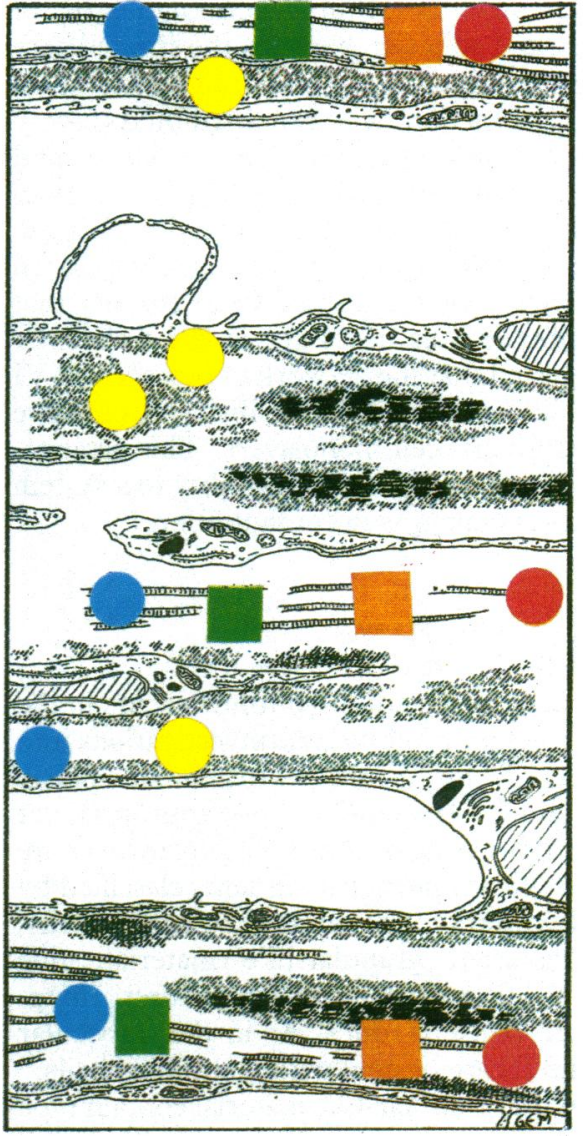

Outer wall

Schlemm's canal

Cribriform layer

Intertrabecular space

Corneoscleral meshwork

Figure 6 Distribution of collagens I-VI in aged human trabecular meshwork. Type I collagen (blue circle) is present in striated collagen fibrils in trabecular beams and the outer wall of Schlemm's canal as well as in basement membranes. Type III collagen (green square) is restricted to striated collagen fibrils. Type IV collagen (yellow circle) is localised over endothelial cell basement membranes and basal lamina-like material. Types $V$ (brown square) and VI collagen (red circle) share a similar distribution to type III collagen (green square) except that they are not directly associated with the collagen fibrils.

I, III, and IV collagen in the trabecular meshwork. ${ }^{77882} \mathrm{~A}$ subsequent immunofluorescence study described the distribution of collagens I, III, IV, and $\mathrm{V} .^{83}$ The basement membranes of the trabecular beams contained types III, IV, and V collagen, the central core contained collagens I and III, while only type III collagen was detected in the outermost layer (juxtacanalicular meshwork; cribriform layer).$^{83}$ In a separate study, weak knot-like staining for type VI collagen was described within the basement membranes underneath the trabecular beam endothelium. ${ }^{84}$ With the resolution of electron microscopy, types I and III collagen have been located to striated fibrils in the cores of the trabecular beams. ${ }^{85}$ Montes $e t a l^{3}$ have suggested that these two collagen types would impart tensile strength (type I) and resilience (type III) to the trabecular 'skeleton' - physical characteristics which are obviously an essential requirement for the biomechanical demands made on the trabecular beams. ${ }^{85}$ One of our own surprising preliminary observations was the presence of type I collagen in the basement membranes of endothelial cells lining the trabecular beams. ${ }^{85}$ This was unexpected because like types II and III, type I has been classified as an integral component of fibrous collagen forming the characteristic $65 \mathrm{~nm}$ periodic striated collagen fibrils. ${ }^{86}$ No examples of such fibrils were observed in the endothelial basement membranes. This raises the interesting possibility that type I collagen, like type $\mathrm{V}$, does not always form striated fibrils and merits further investigation.

Types V and VI collagen appear to be located to a fine filamentous network throughout the collagen fibril core of the trabecular beams. ${ }^{85}$ We suggested that collagens V and VI 
have a dual function in maintaining the structural integrity of the striated fibril core and adhesion between the striated core and the basement membranes of the trabecular endothelial cells. ${ }^{85}$ This anchoring function has been attributed to very fine non-banded fibrils shown to contain type $V$ collagen and which are enmeshed among the striated fibrils. ${ }^{4}$ The functional demands on the trabecular meshwork could explain the difference in distribution of type $\mathrm{V}$ collagen in comparison with that of the cornea. We see no reason to suspect that control of fibril diameter is as necessary in the trabecular meshwork. It is suggested that the network of types V and VI collagen permit the sliding of the collagen fibril cores relative to their adjacent endothelial cell monolayers. This arrangement would impart a greater degree of flexibility to a system that is subject to constant changes in configuration.

\section{COLLAGENS AND AQUEOUS OUTFLOW} RESISTANCE (CRIBRIFORM LAYER)

The suggestion that major resistance to outflow occurs in the cribiform layer ${ }^{87}$ has stimulated numerous investigations into the nature and role of the various extracellular matrix components at that site ${ }^{88-94}$ It would be very appropriate at this point to reiterate that the cells of the cribriform layer are surrounded by extracellular matrix constituents classified by their ultrastructural appearance as striated collagen fibrils, basal lamina-like material, granular-like material, fine fibrillar-like material, fibrous long-spacing fibres (longspacing collagen), and dense plaques. As in the trabecular beams, collagens I and III are present within striated fibrils. ${ }^{85}$ Basal lamina-like and fine granular-like material contain type IV collagen and the basement membrane of the lining endothelium of the inner wall of Schlemm's canal contains both types I and IV collagen. ${ }^{85} 95$ Immunocytochemical localisation of collagen types does not address the question of the origin of extracellular matrix in the cribriform layer which could have been washed through with the aqueous. Determining the contribution of indigenous cells would require the application of mRNA probes (in situ hybridisation) for each of the extracellular matrix components present.

\section{LONG-SPACING COLLAGEN}

Long-spacing collagen (fibrous long-spacing fibres), so described because of its 'zebra-like' alternating thick electron dense and lucent bands, is a hallmark of aging ocular extracellular matrix. An immunoelectron microscope study of tangential sections through the cribriform layer in the region of the scleral spur, localised type VI collagen to fibrous long-spacing fibres (long-spacing collagen). ${ }^{84}$ However, this has not been confirmed by subsequent immunogold electron microscope studies on aged meshwork, ${ }^{85}$ Bruch's membrane (unpublished observations), or corneal stroma ${ }^{49}$ in which fibrous long-spacing fibres (long-spacing collagen) were also present. From our own studies it appears that collagen types I-VI are absent from fibrous long-spacing fibres and in addition it is unlikely that these structures will be found to contain collagen types VII to XII as collagenases do not eliminate the wide electron dense bands ${ }^{\%}$ (collagen types VII-XII are particularly sensitive to collagenases). ${ }^{97}$ Thus there appears as yet no justification for considering longspacing structures as collagen derivatives and the term, long-spacing collagen, may be a misnomer.

Iris

Striated collagen fibrils are the major component of the iris stroma, providing mechanical support for a tissue which undergoes continual changes in configuration. In iris vessels, basement membrane coats the abluminal surface of the endothelial cells and completely surrounds the vascular supporting cells (myocytes and pericytes). Basement membrane is also present on the basal surfaces of the iris pigment epithelium - that is, the muscular extensions of the anterior pigmented epithelium and the posterior surface of the iris.

\section{IRIS COLLAGEN TYPES}

There is very little documentation of iris collagens either by immunomorphology or by biochemical analysis. Type I collagen appears to be the most prevalent collagen in iris tissue, being present both in striated fibrils and basement membranes. ${ }^{98}$ Type III collagen is present within striated fibrils. ${ }^{98}$ The presence of type I collagen in iris basement membranes ${ }^{9899}$ is somewhat surprising as it is not traditionally viewed as a basement membrane component.$^{86}$ Within the iris vasculature it was found to be principally restricted to the extracellular matrix enclosing the vascular supporting cells. ${ }^{98}$ The reverse was true for type IV collagen which was mainly present in the subendothelial basement membrane. This pattern of distribution led us to suggest that within the iris vasculature the synthesis of type I collagen is a responsibility of the myocytes and pericytes, rather than the endothelial cells. ${ }^{98}$ Conversely, type IV collagen appears to be synthesised by endothelial cells rather than the vascular supporting cells. Both collagens I and III are present in the striated fibrils of the double-layered sheath of the iris vessels. ${ }^{98}$ Light microscopic immunohistochemistry has located type VI collagen to this region, and thus it may connect the vascular basement membranes to the surrounding vascular sheath. ${ }^{100}$

Collagen types I, IV, and VI are present in the matrix in which the dilator muscle is embedded. ${ }^{98100}$ It has been suggested that type VI collagen resembles type VII, in that it is involved in adhesion between basement membranes and the adjacent connective tissue. ${ }^{100}$ Thus, the functional role of type VI collagen in this location is seen as adhesion of the dilator muscle basement membrane to the iris stroma. ${ }^{100}$

\section{Ciliary body}

The physical barriers provided by the basement membranes of the ciliary epithelium may influence aqueous humour formation and transportation. In addition, the stromal components of the ciliary processes which surround the fenestrated capillaries may impede fluid exchange between the vascular lumen and ciliary epithelium. Marked morphologic changes arising from collagen deposition occur in the aging ciliary body. ${ }^{101}$ There is as yet no evidence that fibrosis in the ciliary processes has an effect on inflow but fibrosis in the circular and oblique components of the ciliary muscle is accompanied by a decrease in the amplitude of accommodation. ${ }^{102}$

\section{COLLAGENS OF CILIARY BODY}

Biochemical analysis of the collagen content of the ciliary body is limited to one study of the bovine eye in which the presence of types I and III collagen was reported. ${ }^{103}$ Striated collagen fibrils in the stroma exhibited strong labelling for types I and III collagen, ${ }^{104}$ which is a labelling pattern characteristic of extensible tissues. ${ }^{105}$ Both collagen types were present in the ciliary epithelial basement membranes and type I collagen was also present in vascular basement membranes. ${ }^{104}$ The presence of type III collagen in the epithelial basement membranes was of great surprise, as this collagen type had not been localised in other studies of basement membranes of the aged human iris, ${ }^{98}$ retina, ${ }^{106}$ cornea, ${ }^{31}$ and trabecular meshwork. ${ }^{85}$

In a light and electron microscopic study by Rittig et al, ${ }^{100}$ 
BM

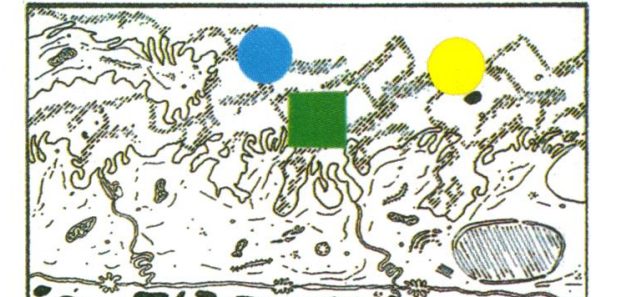

Non-pigmented ciliary epithelium

Pigmented ciliary epithelium

Ciliary muscle

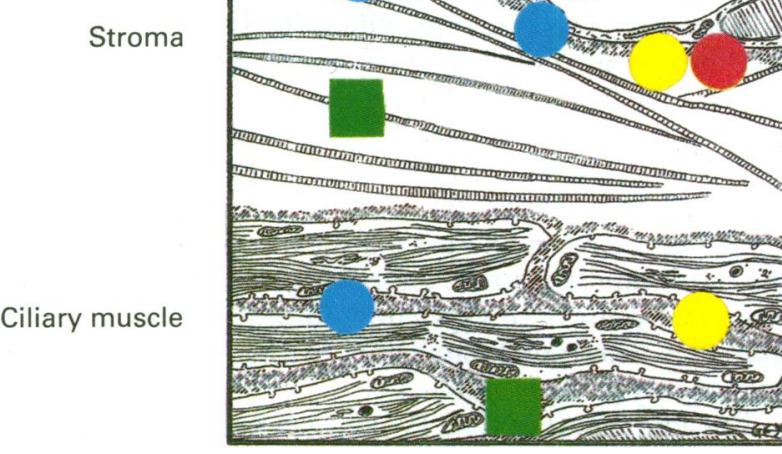

Figure 7 Distribution of collagens I-VI in human ciliary body. Collagens I (blue circle) and III (green square) are present in the basement membranes (BM) of the pigmented and non-pigmented ciliary epithelium and ciliary muscle and over striated collagen fibrils in the ciliary body stroma. Type I collagen (blue circle) is also present in vascular basement membranes. Type $I V$ collagen (yellow circle) is present in all the basement membranes. Type

VI collagen (red circle) exhibits an asymmetric distribution over nonfenestrated regions of capillaries in the ciliary processes and subjacent connective tissue.

types IV and VI collagen were located in the ciliary muscle basement membranes and in vascular basement membranes. Type VI collagen was largely located over the non-fenestrated regions of the capillaries in the ciliary processes. The conclusion was that type VI collagen would mechanically anchor the capillaries without impeding water and solute movement through the fenestrations. ${ }^{100}$ The distribution of collagen types I-VI in the ciliary body is summarised in Figure 7.

\section{Lens capsule}

According to biochemical analysis, lens capsule has a high collagen content (69\% (SD8\%)) ${ }^{103}$ comparable with that of cornea $(69 \cdot 2 \%)$ and sclera $(76 \%) .{ }^{107}$ The biochemical detection of type IV collagen in mammalian lens capsule has been widely reported, ${ }^{103}{ }^{108-111}$ and is estimated to be about $30-40 \%$ of the dry weight of the lens capsule. Barnard et $a l^{112}$ suggested that type IV collagen supplies the strength and flexibility of this basement membrane. Its presence in the lens capsule has been confirmed, both by immunofluorescence microscopy ${ }^{113}$ and by immunogold electron microscopy. ${ }^{114}$ If type IV collagen were the only collagen type present $x$ ray diffraction studies should reveal a chicken wire meshwork arrangement which is peculiar to type IV collagen. ${ }^{115}$ However, the $x$ ray diffraction studies of Barnard et $a^{112}$ failed to show this arrangement, but demonstrated $10 \mathrm{~nm}$ banded microfibrils: the latter may have been the result of the association of collagen types I, III, and IV.
The lens capsule increases in thickness with age and this accretion process appears to be due to completely uniform assembly of three types of collagen (I, III, and IV). ${ }^{114}$ The possibility cannot be excluded that this phenomenon is intrinsic to aging and that these collagens may not be present in the human capsule in the early decades (these data are not yet available). The occurrence of type III collagen in ocular basement membranes is peculiarly unique to the lens capsule and ciliary epithelial basement membranes. Type III collagen is associated with tissues that have elastic properties, ${ }^{3}$ an essential feature of the lens capsule which makes the lens more spherical in accommodation; a tendency which is opposed by tension on the zonular fibres. The role of type I collagen in the lens capsule is uncertain, but it has to be assumed that it imparts tensile strength. ${ }^{3}$

\section{Vitreous}

Vitreous collagen fibrils are oriented randomly to form an irregular mesh in which hyaluronic acid molecules are trapped and are inserted into the basement membrane of the Mueller and glial cells of the retina. The resulting architecture provides both a deformability and rigidity that supports the vitreous body against the surrounding structures. Vitreous collagen fibrils have a diameter of about $15 \mathrm{~nm}$ and an ill defined axial periodicity of $22 \mathrm{~nm}$ which is characteristic of embryonic or immature collagen fibrils. ${ }^{116}$ Type II collagen has been identified by various techniques in chick and bovine vitreous $\mathrm{s}^{3017-119}$ and is the major fibril-forming collagen. To our knowledge, type II collagen has not yet been identified in human vitreous. Type IX collagen is present on the fibril surface and its precise form appears to be tissue and species specific. ${ }^{21}$ That of chick vitreous is attached to an extremely long chondroitin sulphate chain, ${ }^{22}$ while that in bovine vitreous possessed a single chondroitin/dermatan chain. ${ }^{21}$ Bishop et $a l^{21}$ concluded that such differences are likely to be of importance in determining the biochemical and morphological characteristics of the tissue.

\section{Retinal vessels}

Collagens I, IV, and V have been localised by immunofluorescence to vessels of the human retina. ${ }^{120}{ }^{121}$ Jerdan and Glaser ${ }^{120}$ found that a broad spectrum of retinal vessels stained for types I and IV collagen, while types III and V collagen were restricted to the walls of larger vessels.

In our immunoelectron microscope study of aged human retinal vessels, ${ }^{106}$ collagen types I, III, IV, V, and VI were found in larger vessels. Types I, IV, and V with small amounts of III and VI were present in small vessels, and types I, IV, and V in capillary basement membranes. With aging, the thickened walls of retinal vessels consisted mainly of types I, IV, and VI collagen. ${ }^{106}$

Microvessel preparations from rabbit cerebrum as well as bovine retinal microvessels have been shown to contain type I collagen. ${ }^{122}{ }^{123}$ On finding this collagen type in retinal vessels, including capillaries, Jerdan and Glaser ${ }^{120}$ suggested that it is the presence of type I collagen that makes the human retinal vasculature so uniquely resistant to trypsin digestion. The structure of type I collagen has a greater stability to digestion by this protease. ${ }^{124}$

Type IV collagen was more abundant in the outer basal lamina of the intramural pericytes than in that of the endothelial cells. ${ }^{106}$ This difference may be very significant if, from it, one assumes that pericytes produce more type IV collagen than endothelial cells. There is considerable evidence that changes in ECM components, including collagens, can have profound effects on endothelial cell behaviour. For example, type IV collagen was shown by Roberts and Forrester ${ }^{125}$ to inhibit retinal vessel endothelial 
cell migration and proliferation in vitro, whereas type I collagen stimulated cell migration in vitro. Pericyte loss is an early abnormality in diabetes, presumably leading to a decrease in the amount of type IV collagen and thus removing the inhibiting influence that this collagen type has on endothelial cell migration and proliferation.

\section{Bruch's membrane}

Various attempts have been made to determine the collagenous constituents of Bruch's membrane using immunohistochemistry, and collagen types I and III-V have been demonstrated by light microscopy. ${ }^{126-129}$

The ultrastructural location of collagen types I-VI in the five layers of Bruch's membrane is summarised in Figure 8. The $65 \mathrm{~nm}$ striated collagen fibrils contain types I, III, and V and the choriocapillaris basement membrane, collagen type IV. ${ }^{128}$ Labelling for collagen type IV was dense over the basement membrane of the choriocapillaris but weak over the basement membrane of the retinal pigment epithelium. ${ }^{128} 129$ This unexpected discrepancy between epithelial basement membranes and endothelial basement membranes is not confined to Bruch's membrane as it has been noted between epithelial and endothelial basement membranes in cornea $^{3153}$ and ciliary body. ${ }^{104}$ The discrepancy may

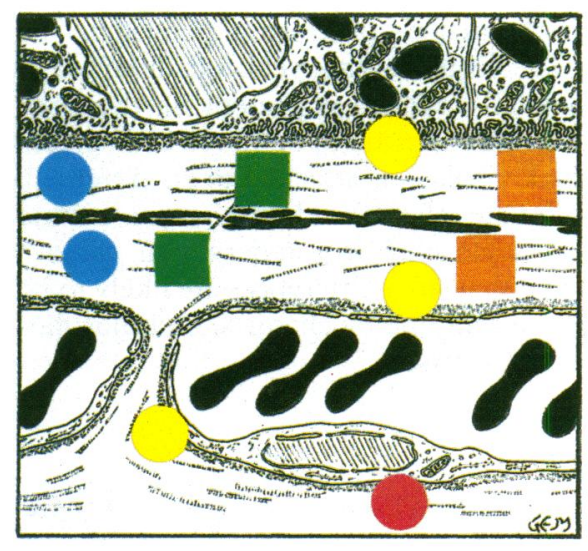

RPE

\section{RPE BM}

ICL

Elastic layer

OCL

BM

Choriocapillaris

BM

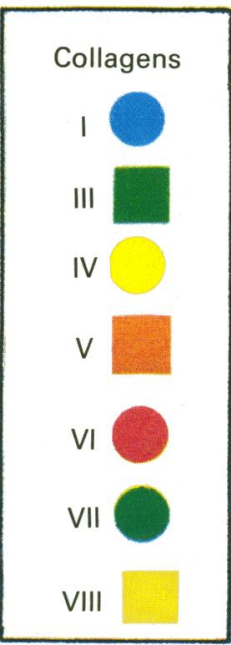

Figure 8 Distribution of collagen types I-VI in aged human macular choroid. Collagens I (blue circle), III (green square), V (brown square) were localised to striated collagen fibrils in the inner (ICL) and outer collagenous layer (OCL) of Bruch's membrane and in the choroidal stroma. Type I collagen (blue circle) is more prominent in the choroidal stroma than in Bruch's membrane. Collagen type IV (yellow circle) is localised principally to the basement membrane of the choriocapillaris $(B M)$ although a little labelling is present over the retinal pigment epithelial basement membrane (RPE BM). Both types V (brown square) and VI collagen (red circle) are also present in the choriocapillaris basement membrane $(B M)$, the latter being asymmetrically restricted to the choroidal side. be due to differences in the availability of antigenic epitopes of the type IV collagen molecule (Essner, personal communication). We concluded from our own unpublished studies on the distribution of collagen types I-VI in macular Bruch's, that only the deposition of type IV collagen in focal thickenings of the choriocapillary basement membranes contributes to the age-related thickening of Bruch's membrane.

In contrast to type IV collagen, which is present throughout the entire circumference of the choriocapillaris, the distribution of type VI collagen was considerably more prominent on the choroidal side (unpublished observations). This suggests that type VI collagen is a product of pericytes which are only present in this location in normal tissue. This co-assembly is also apparent in aged human retinal vessels, where type VI collagen was associated with pericytes and not with endothelial cells. ${ }^{106}$

The asymmetric distribution of type VI collagen in the choriocapillaris is also a feature of the fenestrated capillaries in the ciliary processes (see ciliary body). The asymmetric distribution in the ciliary processes suggests a mechanical anchorage of the fenestrated capillaries without impedance of aqueous flow production. ${ }^{100} \mathrm{We}$ suggest that type VI collagen has a similar function in Bruch's membrane. Considering the great extent to which the choroid can alter its volume in response to oxygen and carbon dioxide levels, anchorage of the choriocapillaris to the underlying choroid is obviously an essential feature of this system. ${ }^{100}$ Impedence of nutrient flow from the fenestrated capillaries to the outer retina would presumably be undesirable.

The abundance of type IV collagen in the choriocapillaris basement membrane may act as an efficient inhibitor of endothelial cell migration ${ }^{125}$ into Bruch's membrane in the normal situation. If, however, endothelial cells breach this barrier the presence of type I collagen in the inner and outer collagenous layers could augment the invasive behaviour of endothelial cells. The absence of type IV collagen beneath the retinal pigment epithelium may therefore be disadvantageous in limiting neovascularisation.

\section{Optic nerve head}

The nerve fibres of the optic nerve are enclosed and segmented by extracellular matrix that provides support and anchorage for the neural elements: the information on human material is based on light microscopic investigations. This extracellular matrix contains collagen types I, III, IV, V, and VI. ${ }^{130}$ Types III, IV, and V collagen present in the prelaminar glial septa are thought to provide structural strength ${ }^{130}$ thereby protecting the delicate axons which pass through the tissue. Type IV collagen present on the surface of the glial septa may serve to anchor the nerve fibres. ${ }^{130}$ An age-relaged increase in the cores within the cribriform plates is associated with an increased density of collagen types I and III. ${ }^{131} \mathrm{An}$ increase in deposition of type IV collagen in basement membranes surrounding blood vessels in the prelaminar and postlaminar regions could be associated with age-related axonal loss. ${ }^{131}$ Morrison et $a l^{132}$ mapped out the fine structural distribution of collagen types I-VI in the monkey optic nerve head by immunogold immunoelectron microscopy. Collagen types I, III, and V were located at striated fibrils in arterial walls, the core of striated fibrils within the lamina cribrosa beams and within the optic nerve septa. Both types IV and V collagen were present in the basement membranes of blood vessels and astrocytes. In an experimental model of glaucomatous optic neuropathy (cynomolgous monkey) extensive glaucomatous optic nerve damage was accompanied by abnormal deposition of collagen types I, III and IV within the laminar pores. ${ }^{133}$ It is interesting to note that intraocular elevation can alter cellular metabolism in the lamina cribrosa: 
there is greater gene expression for type I collagen in lamina cribrosa explant cells grown under high pressure. ${ }^{134}$

G E MARSHALI

A G P KONSTAS

W R LEE

Tennent Institute of Ophthalmology,

Western Infirmary,

1 Berg RA. Intracellular turnover of collagen. In: Mecham RP, ed. Regulation of matrix accumulation. Orlando, FL: Academic Press, 1986: 29-52.

2 Birk DE, Fitch JM, Babiarz JP, Linsenmayer TF. Collagen type I and type $V$ are present in the same fibril in the avian corneal stroma. $f$ Cell Biol 1988; 106: 999-1008.

3 Montes GS, Bezerra MSF, Junqueira LCU. Collagen distribution in tissues. In: Ruggeri A, Motta PM, eds. Ultrastructure of the connective tissue matrix. Boston: Martinus Nijhoff, 1984: 65-88.

4 Modesti A, Kalebic T, Scarpa S, Togo S, Grotendorts G, Liotta LA, Triche $T J$. Type $V$ collagen in human amnion is a $12 \mathrm{~nm}$ fibrillar component of the pericellular interstitium. Eur $\mathcal{F}$ Cell Biol 1984; 35: 246-55.

5 Alberts B, Bray D, Lewis J, Raff M, Roberts K, Watson JD. Molecular biology of the cell. 2nd ed. London: Garland, 1989: 818-9.

6 Abrahamson DR. Recent studies on the structure and pathology of basement membranes. F Pathol 1986; 149: 257-78.

7 Inoue S. Ultrastructure of basement membranes. Int Rev Cytol 1989; 117: 57-98.

8 Laurie GW, Leblond CP. Basement membrane nomenclature (letter). Nature 1985; 313: 272 .

9 Kadoya Y, Yamashina S. Ultrastructure of the basement membrane and its precursor in developing rat submandibular gland as shown by alcian blue staining. Cell Tissue Res 1992; 268: 233-8.

10 Burgeson R, Adli FA, Kaitila II, Hollister DW. Fetal membrane collagens: identifica

11 Roll FJ, Madri JA, Albert J, Furthmayr H. Codistribution of collagen types IV and $\mathrm{AB}_{2}$ in basement membranes and mesangium of the kidney. An

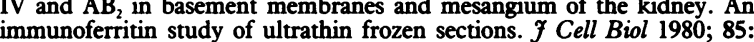
597-616.

12 Briggaman RA. Biochemical composition of the epidermal-dermal junction and other basement membrane. F Invest Dermatol 1982; 78: 1-6.

13 Abedin MZ, Ayad S, Weiss JB. Isolation and native characterization of cysteine-rich collagens from bovine placental tissues and uterus and their relationship to types IV and V collagens. Biosci Rep 1982; 2: 493-502.

14 von der Mark H, Aumailley M, Wick G, Fleischmajer R, Timpl R. Immunochemistry, genuine size and tissue localization of collagen VI. Eurf Biochem 1984; 142: 493-502.

15 Burgeson RE. New collagens, new concepts. Ann Rev Cell Biol 1988; 4: 551-77.

16 Sage H, Trueb B, Bornstein P. Biosynthetic and structural properties of endothelial cell type VIII collagen. $\mathcal{F}$ Biol Chem 1983; 258: 13391-401.

17 Labermeier U, Kenney MC. The presence of EC collagen and type IV collagen in bovine Descemet's membranes. Biochem Biophys Res Commun 1983; 116: 619-25.

18 Sage H, Pritzl P, Bornstein P. A unique, pepsin-sensitive collagen synthesized by aortic endothelial cells in culture. Biochemistry 1980;19: 5747-55.

19 Benya PD, Padilla SR. Isolation and characterization of type VIII collagen synthesized by cultured rabbit corneal endothelial cells: a conventional structure replaces the interrupted helix model. $F$ Biol Chem 1986; 261: 4160-9.

20 Sage H, Bornstein P. Type VIII collagen. In: Mayne R, Burgeson R, eds. Structure and function of collagen types. New York: Academic, 1987: 173-94.

21 Bishop P, McLeod D, Ayad S. Extraction and characterisation of the intact form of bovine vitreous type IX collagen. Biochem Biophys Res Comm 1992; 185: 392-7.

22 Yada T, Suzuki S, Kobayashi K, Kobayashi M, Hoshino T, Horie K, Kimata $K$. Occurrence in chick embryo vitreous humor of a type IX collagen proteoglycan with an extraordinarily large chondroitin sulfate chain and short alpha 1 polypeptide. $\mathcal{J}$ Biol Chem 1990; 265: 6992-9.

23 Miller EJ, Gay S. Collagen: an overview. Methods Enzymol 1982; 82: 3-32.

24 Newsome DA, Gross J, Hassell JR. Human corneal stroma contains three distinct collagens. Invest Ophthalmol Vis Sci 1982; 22: 376-81.

25 Praus R, Brettschneider I, Adam M. Heterogeneity of the bovine corneal collagen. Exp Eye Res 1979; 29: 469-77.

26 Zimmermann DR, Trueb B, Winterhalter KH, Witmer R, Fischer RW. Type VI collagen is a major component of the human cornea. FEBS Lett 1986; 197: 55-8.

27 Ben-Zvi A, Rodrigues MM, Krachmer JH, Fujikawa LS. Immunohistochemical characterization of extracellular matrix in the developing human cornea. Curr Eye Res 1986; 5: 105-17.

28 Nakayasu K, Tanaka M, Konomi H, Hayashi T. Distribution of types I, II, III, IV and V collagen in normal and keratoconus corneas. Ophthalmic Res 1986; 18: $1-10$.

29 Tsuchiya S, Tanaka M, Konomi H, Hayashi T. Distribution of specific collagen types and fibronectin in normal and keratoconus corneas. Fpn f Ophthalmol 1986; 30: 14-31.

30 Von der Mark K, Von der Mark H, Timpl R, Trelstad RL. Immunofluoroscent localization of collagen types I, II and III in the embryonic chick eye.

31 Marshall GE, Konstas AG, Lee WR. Immunogold fine structural localization of extracellular matrix components in aged human cornea. I. Types I-IV collagen and laminin. Graefes Arch Clin Exp Ophthalmol 1991; 229: 157-63.

32 Linsenmayer TF, Fitch JM, Birk DE. Heterotypic collagen fibrils and stabilizing collagens: controlling elements in corneal morphogenesis? Ann NY Acad Sci 1990; 580: 143-60

33 Hendrix MJC, Hay ED, Von Der Mark K, Linsenmayer TF. Immunohistochemical localization of collagen types I and II in the developing chick cornea and tibia by electron microscopy. Invest Ophthalmol Vis Sci 1982; 22: 359-75.

34 Linsenmayer TF, Fitch JM, Schmid TM, Zak NB, Gibney E, Sanderson RD, et al. Monoclonal antibodies against chicken type $\mathrm{V}$ collagen: production, specificity, and use for immunocytochemical localization in the embryonic cornea and other organs. $\mathcal{F}$ Cell Biol 1983; 96: 124-32.

35 Linsenmayer TF, Fitch JM, Gross J, Mayne R. Are the collagen fibrils in the avian cornea composed of two different collagen types? Evidence from monoclonal antibody studies. In: Fleischmajer R, Olsen BR, Kuhn K, eds. Annals of New York Academy of Sciences: Biology, Chemistry and Pathology of Collagen. New York: New York Academy of Sciences, 1986; 460: 232-45.

36 Birk DE, Fitch JM, Linsenmayer TF. Organization of collagen types I and V in the embryonic chicken cornea. Invest Ophthalmol Vis Sci 1986; 27: 1470-7.

37 Linsenmayer TF, Fitch JM, Mayne R. Extracellular matrices in the developing avian eye: type $\mathrm{V}$ collagen in corneal and non corneal tissues. Invest Ophthalmol Vis Sci 1984; 25: 41-7.

38 Bruns RR, Press W, Engvall E, Timpl R, Gross J. Type VI collagen in extracellular $100-\mathrm{nm}$ periodic filaments and fibrils: identification by immunoelectron microscopy. F Cell Biol 1986; 103: 393-404

39 Carter WG. The cooperative role of the transformation-sensitive glycoproteins, GP140 and fibronectin, in cell attachment and spreading. F Biol Chem 1982; 257: 3249-57.

40 Fitch JM, Mentzer A, Mayne R, Linsenmayer TF. Acquisition of type IX Collagen by the developing a

41 Svoboda KK, Nishimura I, Sugrue SP, Ninomiya Y, Olsen BR. Embryonic chicken cornea and cartilage synthesize type IX collagen molecules with different amino-terminal domains. Proc Natl Acad Sci USA 1988; 85: $7496-500$.

42 Keene DR, Sakai LY, Lunstrum GP, Morris NP, Burgeson RE. Type VII collagen forms an extended network of anchoring fibrils. F Cell Biol 1987; 104:611-21.

43 Burgeson RE. Type VII collagen. In: Mayne R, Burgeson R, eds. Structure and function of collagen types. New York: Academic Press, 1987: 145-72.

44 Brewitt H, Reale E. The basement membrane complex of the human corneal epithelium. Graefes Arch Clin Exp Ophthalmol 1981; 215: 223-31.

45 Bentz H, Morris NP, Murray LW, Sakai LY, Hollister DW, Burgeson RE. Isolation and partial characterization of a new human collagen with an extended triple-helical structural domain. Proc Natl Acad Sci USA 1983; 80: 3168-72.

46 Lunstrum GP, Sakai LY, Keene DR, Morris NP, Burgeson RE. Large complex globular domains of type VII procollagen contribute to the structure of anchoring fibrils. $\mathcal{F}$ Biol Chem 1986; 261: 9042-8.

47 Morris NP, Keene DR, Glanville RW, Bentz H, Burgeson RE. The tissue form of type VII collagen is an antiparallel dimer. $\mathcal{F}$ Biol Chem 1986; 261 : $5638-44$

48 Sakai LY, Keene DR, Morris NP, Burgeson RE. Type VII collegen is a major structural component of anchoring fibrils. $\mathcal{F}$ Cell Biol 1986; 103: 1577-86.

49 Marshall GE, Konstas AG, Lee WR. Immunogold fine structural localization of extracellular matrix components in aged human cornea. II. Collagen types V and VI. Graefes Arch Clin Exp Ophthalmol 1991; 229: 164-71.

$50 \mathrm{Schmut} O$. The identification of type III collagen in calf and bovine cornea and sclera. Exp Eye Res 1977; 25: 505-9.

51 Wasano K, Yamamoto T. Microthread-like filaments connecting the epithelial basal lamina with underlying fibrillar components of the connective tissue in the rat trachea. A real anchoring device? Cell Tissue Res 1985; 239: 485-95.

52 Konomi F, Hayashi T, Nakayasu K, Arima M. Localisation of type V collagen and type IV collagen in human cornea, lung and skin. Immunohistochemical evidence by anti-collagen antibodies characterized by immunoelectroblotting. Am F Pathol 1984; 116: 417-26.

53 Cleutjens JP, Havenith MG, Kasper M, Vallinga M, Bosman FT. Absence of type IV collagen in the centre of the corneal epithelial basement membrane. Histochem $F$ 1990; 22: 688-94.

54 Kolega J, Manabe M, Sun T-T. Basement membrane heterogeneity and variation in corneal epithelial differentiation. Differentiation 1989; 42 54-63.

55 Odermatt BF, Lang AB, Ruttner JR, Winterhalter KH, Trueb B. Monoclonal antibodies to human type IV collagen: useful reagents to demonstrate the heterotrimeric nature of the molecule. Proc Natl Acad Sci USA 1984; 81 7343-7.

56 Scheinman JI, Tsai C. Monoclonal antibody to type IV collagen with selective basement membrane localization. Lab Invest 1984; 50: 101-12.

57 SundarRaj N, Willson J. Monoclonal antibody to human basement membrane collagen type IV. Immunology 1982; 47: $133-40$.

58 Azar DT, Spurr-Michaud SJ, Tisdale AS, Gipson IK. Decreased penetration of anchoring fibrils into the diabetic stroma: a morphometric analysis. Arch Ophthalmol 1989; 107: 1520-3.

59 Newsome DA, Foidart J-M, Hassell JR, Krachmer JH, Rodrigues MM, Katz SI. Detection of specific collagen types in normal and keratoconus corneas Invest Ophthalmol Vis Sci 1981; 20: 738-50.

60 Von der Mark K, Ocalan M. Immunofluorescent localization of type V collagen in the chick embryo with monoclonal antibodies. Collagen Rel Res 1982; 2: 541-55.

61 Fitch JM, Birk DE, Mentzer A, Hasty KA, Mainardi C, Linsenmayer TF. Corneal collagen fibrils: dissection with specific collagenases and monoclonal antibodies. Invest Ophthalmol Vis Sci 1988; 29: 1125-36.

62 Timpl R, Engel J. Type VI collagen. In: Mayne R, Burgeson R, eds. Structure and function of collagen types. New York: Academic Press, 1987: 105-43.

63 Bruns RR. Beaded filaments and long-spacing fibrils: relation to type VI collagen. F Ultrastruct Res 1984; 89: 136-45.

64 Schittny JC, Dziadek M, Timpl R, Engel J. Localization of type VI collagen and of the basement membrane components laminin, nidogen, type IV collagen and low density proteoglycan in the mouse eye by indirec immunofluores

65 Sawada H, Konomi H, Hirosawa K. Characterization of the collagen in the hexagonal lattice of Descemet's membrane: its relation to type VII collagen. F Cell Biol 1990; 110: 219-27.

66 Tamura Y, Konomi H, Sawada H, Takashima S, Nakajima A. Tissue distribution of type VIII collagen in human adult and fetal eyes. Invest Ophthalmol Vis Sci 1991; 32: 2636-44.

67 Benya PD. EC collagen: biosynthesis by corneal endothelial cells and . Renal Physiol 1980; 3: 30-5.

68 Kay EP, Oh S. Modulation of type III collagen synthesis in bovine corneal endothelial cells. Invest Ophthalmol Vis Sci 1988; 29: 200-7.

69 Cox JL, Farrell RA, Hart RW, Langham ME. The transparency of the mammalian cornea. $\mathcal{F}$ Physiol 1970; 210: 601-16. 
70 Broek DL, Madri JA, Eikenberry EF, Brodsky B. Characterization of the tissue form of type V collagen from chick bone. $\mathcal{F}$ Biol Chem 1985; 260: 555-602.

71 Freeman IL. The eye. In: Weiss JB, Jayson MIV, eds. Collagen in health and disease. London: Churchill Livingstone, 1982: 388-403.

72 Hong B-S, Davison PF, Cannon DJ. Isolation and characterization of a distinct type of collagen from bovine fetal membranes and other tissues. Biochemistry 1979; 18: 4278-82.

73 Silver FH, Birk DE. Molecular structure of collagen in solution: comparison of types I, II, III and V. Int $\mathcal{F}$ Biol Macromol 1984; 6: 125-32.

74 Adachi $E$, Hayashi $T$. In vitro formation of hybrid fibrils of type $V$ collagen and type I collagen: limited growth of type I collagen into thick fibrils by type V collagen. Connect Tissue Res 1986; 14: 257-66.

75 Scott JE. Proteoglycan: collagen interactions and corneal ultrastructure. Biochem Soc Trans 1991; 19: 877-81.

76 Keeley FW, Morin JD, Vesely S. Characterization of collagen from normal human sclera. Exp Eye Res 1984; 39: 533-42.

77 Rehnberg M, Ammitzboll T, Tengroth B. Collagen distribution in the lamina cribrosa and the trabecular meshwork of the human eye. Br $\mathcal{F}$ Ophthalmol 1987; 71: 886-92.

78 Tengroth B, Rehnberg M, Amitzboll T. A comparative analysis of the collagen type and distribution in the trabecular meshwork, sclera, lamina cribrosa and the optic nerve head in the human eye. Acta Ophthalmol 1985; 63 (suppl): 91-3.

79 Marshall GE, Konstas AGP, Lee WR. Collagens in the aged human macular sclera. Curr Eye Res 1993; 12: 143-53.

80 Yamabayashi S, Ohno S, Aguilar RN, Furuya T, Hosoda M, Tsukahara S. Ultrastructural studies of collagen fibres of the cornea and schera by a quickfreezing and deep-etching method. Ophthalmic Res 1991; 23: 320-9.

81 Parry DAD, Craig AS. Growth and development of collagen fibrils in connective tissue. In: Ruggeri A, Motta PM, eds. Ultrastructure of the connective tissue matrix. Boston: Martinus Nijhoff, 1984: 34-64.

82 Konomi H, Hyashi T, Sano J, Terato K, Nagai Y, Arima M, et al. Immunohistochemical localization of type I, III and IV collagens in the sclera and choroid of bovine,

83 Murphy CG, Yun AJ, Newsome DA, Alvarado JA. Localization of extracellular proteins of the human trabecular meshwork by indirect immunocellular proteins of the human trabecular meshw
fluorescence. Am $\mathcal{O}$ Ophthalmol 1987; 104: 33-43

84 Lutjen-Drecoll E, Rittig M, Rauterberg J, Jander R, Mollenhauer J. Immunomicroscopical study of type VI collagen in the trabecular meshwork of normal and glaucomatous eyes. Exp Eye Res 1989; 48: 139-47.

85 Marshall GE, Konstas AGP, Lee WR. Immunogold ultrastructural localization of collagens in the aged human outflow system. Ophthalmology 1991; 98: 692-700.

86 Kuhn K. The classical collagens: types I, II and III. In: Mayne R, Burgeson R, eds. Structure and function of collagen types. New York: Academic Press, 1987: 1-42.

87 Bill A, Svedbergh B. Scanning electron microscopic studies of the trabecular meshwork and the canal of Schlemm - an attempt to localize the main resistance to outflow of aqueous humor in man. Acta Ophthalmol 1972; 50: resistance

88 Grierson I, Lee WR. Acid mucopolysaccharides in the outflow apparatus. Exp Eye Res 1975; 21: 417-31.

89 Inomata H, Bill A, Smelser GK. Aqueous humor pathways through the trabecular meshwork and into Schlemm's canal in the cynomolgus monkey (Macaca irus): an electron microscopic study. Am $\mathcal{F}$ Ophthalmol 1972; 73: 760-89.

90 Rohen JW. Why is intraocular pressure elevated in chronic simple glaucoma? Anatomical considerations. Ophthalmology 1983; 90: 758-65.

91 Rohen JW. Anatomy of the aqueous outflow channels. In: Cairns JE, ed. Glaucoma. London: Grune and Stratton, 1986.

92 Rohen JW, Futa R, Lutjen-Drecoll E. The fine structure of the cribriform meshwork in normal and glaucomatous eyes as seen in tangential sections. Invest Ophthalmol Vis Sci 1981;21: 574-85.

93 Segawa K. Ultrastructural changes of the trabecular tissue in primary open angle glaucoma. Fpn $\mathcal{F}$ Ophthalmol 1975; 19: 317-38.

94 Tawara A, Varner HH, Hollyfield JG. Distribution and characterization of sulfated proteoglycans in the human trabecular tissue. Invest Ophthalmol Vis Sci 1989; 30: 2215-31.

95 Marshall GE, Konstas AG, Lee WR. Immunogold localization of type IV collagen and laminin in the aging human outflow system. Exp Eye Res 1990; 51: 691-9.

96 Mayne R, Burgeson R. Structure and function of collagen types. New York: Academic Press, 1987

97 Lutjen-Drecoll E, Futa R, Roben JW. Ultrahistochemical studies on tangential sections of the trabecular meshwork in normal and glaucomatous eyes. Invest Ophthalmol Vis Sci 1981; 21: 563-73.

98 Konstas AG, Marshall GE, Lee WR. Immunocytochemical localisation of collagens (I-V) in the human iris. Graefes Arch Clin Exp Ophthalmol 1990; 228: $180-6$.

99 Konstas AGP, Marshall GE, Lee WR. Iris vasculopathy in exfoliation syndrome: an immunocytochemical study. Acta Ophthalmol 1991; 69: 472-83.

100 Rittig M, Lutjen-Drecoll E, Rauterberg J, Jander R, Mollenhauer J. Type-VI collagen in the human iris and ciliary body. Cell Tissue Res 1990; 259: 305-12.

101 Lee WR. Ophthalmic histopathology. London: Springer Verlag, 1993: 20.

102 Naumann GOH. Uvea. In: Naumann GOH, Apple DJ, eds. Pathology of the eye. New York: Springer Verlag, 1986: 413-507.
103 Schmut $O$. The organization of tissues of the eye by different collagen types. Graefes Arch Clin Exp Ophthalmol 1978; 207: 189-99.

104 Marshall GE, Konstas AGP, Abraham S, Lee WR. Extracellular matrix in aged human ciliary body: an immunoelectron microscope study. Invest Ophthalmol Vis Sci 1992; 33: 2546-60.

105 Weiss JB, Jayson MIV. Collagen in health and disease. Edinburgh: Churchill Livingstone, 1982.

106 Marshall GE, Konstas AG, Lee WR. Ultrastructural distribution of collagen types I-VI in aging human retinal vessels. Br f Ophthalmol 1990; 74:

107 Polatnick J, LaTessa AJ, Katzin HM. Comparisons of collagen preparations from beef cornea and sclera. Biochem Biophys Acta 1957; 26: 365-9.

108 Dehm P, Kefalides NA. The collagenous component of lens basement membrane. The isolation and characterization of an alpha chain size collagenous peptide and its relationship to newly synthesized lens components. F Biol Chem 1978; 253: 6680-6.

109 Gay S, Miller EJ. Characterization of lens capsule collagen: evidence for the presence of two unique chains in molecules derived from major basement membrane structures. Arch Biochem Biophys 1979; 198: 370-8.

110 Mohan PS, Spiro RG. Macromolecular organization of basement membranes: characterization and comparison of glomerular basement membrane and lens capsule components by immunochemical and lectin affinity procedures. $\mathcal{F}$ Biol Chem 1986; 261: 4328-36.

111 Sundar-Raj CV, Freeman IL. Structure and biosynthesis of rabbit lens capsule collagen. Invest Ophthalmol Vis Sci 1982; 23: 743-56.

112 Barnard K, Gathercole LJ, Bailey AJ. Basement membrane collagen evidence for a novel molecular packing. FEBS Lett 1987; 212: 49-52.

113 Hettlich HJ, Wenzel M, Janssen M, Mittermayer C. Immunhistochemische Untersuchungen der menschlichen Linsenkapsel. Fortschr Ophthalmol 1990; 87: 147-9.

114 Marshall GE, Konstas AGP, Bechrakis NE, Lee WR. An immunoelectron microscope study of the aged human lens capsule. Exp Eye Res 1992; 54: 393-401.

115 Timpl R, Wiedemann H, Van Delden V, Furthmayr H, Kuhn K. A network model for the organisation of type IV collagen molecules in basement membranes. Eur f Biochem 1981; 120: 203-11.

116 Constable IJ. Pathology of vitreous membranes. In: Freeman HM, Hirose T, Schepens CL, eds. Vitreous surgery and advances in fundus diagnosis and Schepens CL, eds. Vitreous surgery and advances in fundus

117 Linsenmayer TF, Little CD. Embryonic neural retinal collagen: in vitro synthesis of high molecular weight forms of type II plus a new genetic type. Proc Natl Acad SciUSA 1978; 75: 3235-9.

118 Smith GN Jr, Linsemayer TF, Newsome DA. Synthesis of type II collagen in vitro by embryonic chick neural retina tissue. Proc Natl Acad Sci USA 1976; 73: 4420-3.

119 Swann DA, Constable IJ, Harper E. Vitreous structure. 3: Composition of bovine vitreous collagen. Invest Ophthalmol 1972; 11: 735-8.

120 Jerdan JA, Glaser BM. Retinal microvessel extracellular matrix: an immunofluorescent study. Invest Ophthalmol Vis Sci 1986; 27: 194-203.

121 Newsome DA, Hewitt AT. Laminin detection in normal and retinitis pigmentosa human retina. Curr Eye Res $1985 ; 4: 925-32$.

122 Faris B, Mozzicato P, Ferrara R, Glenbourtt M, Foselli P, Franzblau C. Collagen of brain microvessel preparations. Microvasc Res 1976; 23: 171-9.

123 Kennedy A, Frank RN, Mancini MA, Lande M. Collagens of the retinal microvascular basement membrane and of retinal microvascular cells in vitro. Exp Eye Res 1986; 42: 177-99.

124 Miller EJ, Finch JE, Chung E, Bulter WT, Robertson PB. Specific cleavage of the native type III collagen molecule with trypsin. Similarity of the cleavage products to collagenase produced fragments and primary structure at the cleavage site. Arch Biochem Biophys 1976; 173: 631-7.

125 Roberts JM, Forrester JV. Factors affecting the migration and growth of endothelial cells from microvessels of bovine retina. Ext Eye Res 1990; 50: 165-72.

126 Campochiaro PA, Jerdan JA, Glaser BM. The extracellular matrix of the human retinal pigment epithelial cells in vivo and its synthesis in vitro. human retinal pigment epithelial cells in vivo

127 Newsome DA, Hewitt AT, Huh W, Robey PG, Hassell JR. Detection of specific extracellular matrix molecules in drusen, Bruch's membrane and ciliary body. Am $\mathcal{F}$ Ophthalmol 1987; 104: 373-81.

128 Das A, Frank RN, Zhang NL, Turczyn TJ. Ultrastructural localization of extracellular matrix components in human retinal vessels and Bruch's membrane. Arch Ophthalmol 1990; 108: 421-9.

129 Marshall GE, Konstas AGP, Reid GG, Edwards JG, Lee WR. Type IV collagen and laminin in Bruch's membrane and basal linear deposit in the human macula. Br 7 Ophthalmol 1992; 76: 607-14.

130 Goldbaum MH, Jeng SY, Logemann R, Weinreb RN. The extracellular matrix of the human optic nerve. Arch Ophthalmol 1989; 107: 1225-31.

131 Hernandez MR, Luo XX, Andrzejewska W, Neufeld AH. Age-related changes in the extracellular matrix of the human optic nerve head. Am f Ophthalmol 1989; 107: 476-84.

132 Morrison JC, L'Herault NL, Jerdan JA, Quigley HA. Ultrastructural location of extracellular matrix components in the optic nerve head. Arch Ophthalmol 1989; 107: 123-9.

133 Morrison JC, Dorman-Pease ME, Dunkelberger GR, Quigley HA. Optic nerve head extracellular matrix in primary optic nerve head atrophy and experimental glaucoma. Arch Ophthalmol 1990; 108: 1020-4

134 Quigley HA, Brown A, Dorman-Pease ME. Alterations in elastin of the optic nerve head in human and experimental glaucoma. Brf Ophthalmol 1991;75: 552-7. 
patients with Sorsby's fundus dystrophy and age-related macular degeneration was thought to be caused by thickening of Bruch's membrane interfering with metabolic exchange across Bruch's membrane between the choriocapillaris and the retinal pigment epithelium. The results may indicate that Bruch's membrane changes associated with peau d'orange in patients with PXE have little effect on function and seem not to interfere significantly with delivery of the metabolic substrates necessary for normal function to the photoreceptor cells.

$$
\begin{array}{r}
\text { FRANK G HOLZ } \\
\text { CHRIS JUBB } \\
\text { FREDERICK W FITZKE } \\
\text { ALAN C BIRD } \\
\text { Department of Clinical Ophthalmology } \\
\text { and Visual Science, } \\
\text { Institute of Ophthalmology, } \\
\text { Moorfields Eye Hospital, } \\
\text { City Road, London ECIV 2PD } \\
\text { F MICHAEL POPE } \\
\text { Medical Research Centre, } \\
\text { Department of Dermatology, } \\
\text { Northwick Park Hospital, } \\
\text { Watford Road, Harrow, } \\
\text { Middlesex HAI } 3 U \mathscr{y}
\end{array}
$$

1 Pope FM. Historical evidence for the genetic heterogeneity of pseudoxanthoma elasticum. $B$ f Dermatol 1975; 92: 493-509.

2 Shields JA, Federman JL, Tomer TL, Annesley WH. Angioid streaks. I Ophthalmoscopic variations and diagnostic problems. $\mathrm{Br} \mathcal{F} O$ phthalmol 1975; 59: 257-66.

3 Smith JL, Gass JDM, Justice J. Fluorescein fundus photography of angioid streaks. $\mathrm{Br} \mathcal{f}$ Ophthalmo 1964; 48: 517-21.

4 Bischler V. Le fond muchté multicolor, manifestation fruste de la maladie de GroenbladStrandberg. Bull Mem Soc Fr Ophtalmol 1955; Strandberg.

5 Shimuzu K. Mottled fundus in association with pseudoxanthoma elasticum. Fap $\mathcal{F}$ Ophthalmo 1961; 5: 1-13.

6 Krill AE, Klien BA, Archer DB. Precursors of angioid streaks. Am $\mathcal{F}$ Ophthalmol 1973; 76 875-9.

7 Steinmetz RL, Polkinghorne PC, Fitzke FW, Kemp CM, Bird AC. Abnormal dark adaptation and rhodopsin kinetics in Sorsby's fundus dystrophy. Invest Ophthalmol Vis Sci 1992; 33: $1633-6$.

8 Steinmetz RL, Haimovici R, Jubb C, Fitzke FW, Bird AC. Symptomatic abnormalities of dark adaptation in patients with age-related Bruch's adaptation in patients with age-related Bruch's
membrane change. $B r \mathcal{O}$ Ophthalmol 1993; 77: 549-54.

\section{NOTICES}

\section{Medical Screening: The Way Forward}

Medical screening provides many opportunities for the prevention of disease and handicap. What can it offer and what are its limitations? Based on several case studies, a one day conference entitled Medical Screening: The Way Forward, organised jointly by $B M \mathcal{J}$ and foumal of Medical Screening, will be held on 26 January 1994 at the QE2 Conference Centre, London to examine the medical, scientific, ethical, social, psychological, and economic aspects of screening. For details: Pru Walters, BMA Conference Unit, BMA House, Tavistock Square, London WClH 9JR. (Tel: 071-383 6605; Fax: 071-383 6400.)
Optics '94

Optics '94, an international exhibition on eye wear, technology, and equipment for optometry and opththalmology will be held on 18-20 February 1994 at the World Trade Center, Singapore. A conference on better eye care will be held in conjunction with the exhibition. Further details: Lines Exposition \& Management Services Pte Ltd, 318-B King George's Avenue, Singapore 0820. (Tel: (65) 2998611; Fax: (65) 2998633.)

\section{International Society of Ocular Trauma}

The 3rd International Symposium on Ocular Trauma will be held in Cancun, Mexico in March 1994. Further details: Secretariat, PO Box 50006, Tel Aviv, 61500, Israel. (Tel: (972 3) 5174571; Fax: (972 3) 5175674.)

\section{Third Annual Scientific Meeting of the} Australian Squint Club

The Third Annual Scientific Meeting of the Australian Squint Club will be held in Melbourne, Australia on 4-6 March 1994. Further details: Dr W E Gillies, 82 Collins Street, Melbourne 3000, Australia (tel: 613 654 5860; fax: 613650 4404).

\section{International Ophthalmic Excimer Laser Congress}

The first annual United Kingdom International Ophthalmic Excimer Laser Congress will be held on 15 and 16 April 1994 at Redworth Hall Hotel and Country Club, County Durham. Details: Ms Judith Ritchey, Sunderland Eye Infirmary, Queen Alexandra Road, Sunderland, UK SR2 9HP. (Fax: 091-569 9275.)

\section{Fourth Breton Workshop on Autoimmunity}

The Fourth Breton Workshop on Autoimmunity will be held on 15-16 April 1994 in Brest, France. Further details: Secretariat, Laboratory of Immunology, Brest University Medical School Hospital, BP 824-29 609 Brest cédex, France. (Tel: (33) 9822 33 84; Fax: (33) 98801076 .)

European Society of Traditional Ophthalmology and Traditional Chinese Medicine

The 3rd international symposium of traditional medicine will be held on 12-22 May 1994 in Japan. Further details: Dr J Poletti, Société Européenne d'Ophtalmologie Traditionelle, CHIC Tarbes; BP 1330, 65013 Tarbes Cedex, France. (Tel: 625154 55; Fax: 62515162. .

\section{American Academy of Optometry}

A meeting of the American Academy of Optometry will be held on 28-30 May 1994, at the Amsterdam Marriott Hotel, Amsterdam, The Netherlands. Further details: Academy Office, 4330 East-West Highway, Suite 1117, Bethesda, MD 20814, USA. (Tel: (301) 718-6500; Fax: (301) 656-0989.)
International Conference on Biomedical Periodicals

The International Conference on Biomedical Periodicals will be held on 16-18 June 1994 in Beijing, China. Further details: Dr Yongmao Jiang, International Conference on Biomedica Periodicals, c/o Publishing House of Medical Journals, Chinese Medical Association, 42 Dongsi Xidajie, Beijing 100710, China. (Tel: 86-1-5133311 ext 362; Fax: 86-1-5123754.)

\section{XXVIIth International Congress of Ophthalmology}

The International Council of Ophthalmology will hold its XXVIIth Congress in Toronto Canada on 26-30 June 1994. Further details: Secretariat, 275 Bay Street, Ottawa, Ontario, Canada K1R 5Z5. (Tel: (613) 563-1994; Fax: (613) 236-2727.)

\section{Allied Health Personnel - International Congress of Ophthalmology '94}

The first Allied Health Personnel Conference will be held in conjunction with the XXVIIth International Congress of Ophthalmology on 26-30 June 1994 in Toronto, Canada. Further details: Congress Canada, 191 Niagara Street, Toronto, Canada M5V 1C9. (Tel: (416) 8601772; Fax: (416) 860-0380.)

\section{Welsh Cataract Congress 1994}

The Welsh Cataract Congress 1994 will be held on 8-10 September 1994. Details from: Eula Mae Childs, coordınator, Cullen Eye Institute, Baylor College of Medicine, 6501 Fannin, NC200, Houston, TX 77030, USA. (Tel: (713) 798-5941; Fax: (713) 798-4364.)

Third International Symposium on Ocular Inflammation

The 3rd international symposium on ocular inflammation will be held on 22-25 October 1994 in Fukuoka, Japan. Further details: Registration Secretary, c/o JTB Communications Inc, New Kyoto Center Building, 5F, Shiokoji, Shinmachi, Shimogyo-ku Kyoto 600 , Japan.

\section{Correction}

We regret that, in the perspective in the August issue (1993; 77: 515-24), reference 134 was incorrect. The correct reference is:

134 Yang JL, Neufeld AH, Zorn MB, Hernandez MR. Collagen type I mRNA levels in cultured human lamina cribrosa cells; effects of elevated hydrostatic pressure. Exp Eye Res 1993; 56: $567-74$. 